Poznań

\title{
The Union for the Mediterranean in the policy of France and Germany
}

For centuries the Mediterranean has been France's special influence zone. In the Middle Ages, France, the greatest Catholic empire, was naturally drawn to the holy places of Christianity, setting the routes of pilgrimages and crusades. Its geographical location had made France a Mediterranean power, while ship owners and merchants from Marseille looked eastwards, thinking about trade and the riches of this region. After France annexed Corsica (1768) and conquered Algeria (1832), these tendencies became even more pronounced. Napoleon Bonaparte's adventurous expedition to Egypt, the policy of protectorates in the $19^{\text {th }}$ century (Tunisia and Morocco) and that of mandates of the League of Nations after World War I (Syria and Lebanon) confirmed the French presence in the region (Godnin, Vince, 2012, p. 38 and next).

After World War II, Paris gradually lost its colonies in North Africa. The difficult partition with the colonial empire was symbolised by the bloody war in Algeria (1954-1962) which brought about the collapse of the Fourth and the beginning of the Fifth French Republic. Over the years, however, diplomatic endeavours in the area of economy and culture allowed France to restore its influence in the region. It was thanks to France that the European Community introduced special measures (The Yaounde Convention) in 1963 to facilitate trade between the EC and francophone countries in this region (Baszkiewicz, 1999, chapters 10 and 11).

German interest in this part of Europe and Africa was markedly smaller, despite German active colonial policy after its unification in 1871. German endeavours to participate in co-deciding the fate of Morocco in 1911 eventually failed, however, and Emperor Wilhelm II had to accept the fact that France was the dominant power in the Maghreb (Czapliński, 1992).

During the Cold War, the US Sixth Fleet, France and the UK were the strongest powers in the Mediterranean. West Germany did not get involved, for obvious reasons limiting itself to providing financial and moral support to Israel. After the Iron Curtain fell, public opinion in Germany was most interested in terrorist attacks against German tourists in Egypt.

After reunification, Germany had neither the concept nor the vision of how to develop its policy towards the Mediterranean. The government of Helmut Kohl took part in the establishment of the Euro-Mediterranean Partnership, but it lacked consistency and perseverance. The priorities of the German presidency of the Council of the European Union in 1994, 1999 and even in 2007, approached the issue of cooperation with the Mediterranean highly superficially (Schumacher, 2009). 
Owing to the commitment of France, Italy and Spain, the importance of the Mediterranean in the policy of the European Community and, later, of the European Union was consistently increasing. On the one hand, the states of the South purchased technologically advanced industrial products as well as light industry products (accounting for 9.7\% of EU exports in 2007). Imports from the Mediterranean (Morocco, Tunisia, Libya, Algeria, Egypt, Israel, Palestinian Authority, Jordan, Syria, Lebanon and Turkey) accounted for around $7.7 \%$ of EU import, traditionally including energy resources (20\%), but also foodstuffs, textiles, machinery and equipment (European Union, 2014).

The establishment of the European Union and its enormous expansion to the East and South-East of Europe resulted in an intensified Mediterranean policy. On November 27-28, 1995, the Barcelona Declaration was signed, establishing the Barcelona Process. It was initiated by twelve South and East Mediterranean countries (Egypt, Israel, Syria, Jordan, Lebanon, Morocco, Tunisia, Algeria, Turkey, Malta, Cyprus and the Palestinian Authority), accompanied by fifteen EU member states (Austria, Belgium, Denmark, Germany, Spain, Finland, Greece, Sweden, France, Ireland, the Netherlands, Luxembourg, Italy, Portugal and the United Kingdom). The scope of this organisation's activities was divided into three sectors: political and security partnership, economic and financial partnership as well as social, cultural and humanitarian partnership. At present, the programme formally includes 43 states (a total of over $756 \mathrm{mln}$ citizens) (Wójcik, 2008).

The formula adopted within the Barcelona Process translated into political and economic cooperation, stabilisation of the region and strengthened social dialogue. This was to be supported by association agreements with different countries in the region and by special programmes of financial support. In the first period, the implementation of the Barcelona Process was financed from the budgets of union projects: the Accompanying Measures (Mesures d'Accompagnement) MEDA and MEDA II, as well as the resources provided by the European Investment Bank.

The European Neighbourhood Policy (ENP), established in 2004, approached EU policy towards its closest neighbours and partners in a different and more balanced manner. The Barcelona Process inevitably lost in importance as a new instrument was initiated, namely the European Neighbourhood and Partnership Instrument (ENPI). This became operational in January 2007, replacing the earlier TACIS and MEDA programmes. In the period from 2007-2013, the European Commission declared to allocate approximately 12 bln euro to the ENPI-related programmes. Ten partner countries (Algeria, the West Bank and the Gaza Strip, Egypt, Jordan, Lebanon, Morocco, Syria, Tunisia, Israel and Libya) received 1.3 bln euro from this source in 2007.

Although the tenth anniversary of the Barcelona Process was celebrated in 2005, and new operating programmes were adopted for the years to come, it was noticeable that EU activities in the Mediterranean were declining (Rezolucja, 2005). The Madrid summit of the European Council in December 1995, resolved to start EU enlargement to include East European, Central and East European and South European states. This extremely ambitious project involved both EU resources and the attention of the European Commission. The process of including the countries from these regions in the EU was primarily supported by a reunited Germany, which assumed the role of 'advocate' of Central European interests, using a variety of arguments in Brussels. This direction 
of EU expansion was never a priority for France. The wide opening of the fledgling EU contrasted with the strong tendency of Paris to focus on the deepened cooperation between member states, in order to curb the independence of a reunited Germany. In the early 1990s, Paris did not get involved in the accession of new democracies to the $\mathrm{EC} / \mathrm{EU}$, assuming somewhat fatalistically that Central European countries were traditionally ready to cooperate with a united Germany and would become its 'clients' in the future. Germany was not to be indirectly assisted in strengthening its influence in the EU. French reluctance was to a significant degree reflected in this country's extreme procrastination over further enlargement, criticising the expenses related to the Eastern l'elargissement and demanding that EU budgetary resources be allocated to the development of the Mediterranean (Koszel, 2003; Deubner 1999).

In France's view, another serious matter concerned the necessity of holding back the European aspirations of Turkey, which in 2005 was allowed to start accession negotiations with the EU. The French right wing did not consider Turkey to be a European country, it feared the influx of immigrants, the Islamisation of Europe and increased crime rate. Turkey's accession to the EU would have significantly weakened the position of France. With a larger population and area, Turkey would have 'degraded' France, which would have become the third power in the EU (following Germany and Turkey). France sought a way to discourage Turkey from membership, while offering it close cooperation and an adequate, strategic position in the region, within the framework of 'privileged partnership'. This concept met the full approval of the German Christian Democrats and the new German Chancellor, Angela Merkel, who took power in the autumn of 2005 (Koszel, 2008; Kumoch, 2011).

On account of its historical tradition and long presence in North Africa, France was highly protective of its zone of influence in this region. It did not welcome frequent visits paid by US diplomats in the Maghreb, it also feared Chinese economic expansion there. France tried to use its presence in North Africa to reverse the trends that were in France's opinion unfavourable and were aimed at enlarging the EU to the east and south-east. The decision to start accession negotiations with six East, Central and East, and South European countries was to be made at the meeting of the European Commission in Luxembourg in December 2007.

Therefore, it comes as no surprise that the issue of intensified cooperation in the Mediterranean was one of the key topics of the presidential election campaign in France in 2007, with the exception of the socialists, whose candidate, Ségolène Royal, made no reference to this issue. One candidate for the highest office in France, Minister of the Interior, Nicolas Sarkozy, followed the guidelines of his closest advisor, the Eurosceptic Henri Guaino, and a economic expert, Jean-Louis Guigou, and decided to establish the Mediterranean Union (Union Méditerranée). In this manner he wanted to emphasise the leading role of France in the Mediterranean and to commit EU resources to implement this plan, which was equally important. This was to counterbalance the EU's commitment to the East, ensure a certain equilibrium and block Turkish accession by means of appreciating its role as the most important partner within the Mediterranean Union (Martnes, Thorel, 2013, p. 92).

Sarkozy officially presented the Mediterranean Union project at an election rally in Toulon, on 7 February, 2007. In the passionate manner typical of him, he stressed that 
France as a European, and at the same time Mediterranean state had to take the initiative to establish such a union of Mediterranean countries, the same way it had initiated the European Union project in the past. This was an element of the project intended to restore France's grandeur and create a mare nostrum. The President enumerated Greece, Italy, Portugal, Spain and Cyprus among the initiators of the campaign (Die Zukunft, 2007).

This direction of France's intensified foreign policy, outlined by Sarkozy, to a great extent corresponded with French expectations and sentiments. As early as the 1990s, a certain fashion for North Africa spread among French intellectuals. The merits of French colonialism were remembered, and its contribution to the economic and social advancement of North African countries, as well as the fascination of the local elites with French culture and language. The right-wing candidate for the presidency needed a catchy slogan to remind the descendants of the pieds noirs of their French cultural heritage and encourage them to vote for him. Consequently, criticism was limited and the presidential initiative was met with sympathy (Schmid, 2007, p. 13-23).

After the elections and his investiture (May 16, 2007), President Sarkozy started to fulfil his election promises to set up a Mediterranean Union. In his first speech as President, given at the Place de la Concorde in Paris, Sarkozy declared that the project of the Union was more than mere election propaganda, he treated it seriously and intended to implement it soon. After initial public opinion surveys, made in the summer of 2007, at a traditional meeting of French ambassadors in Paris, held on August 26, President Sarkozy reiterated that he attached great importance to the implementation of his ideas and asked the diplomats to disseminate this idea. This topic was an inseparable element of his speeches given during his visit to North Africa (Tangier in October and Algiers and Cairo in December).

Initially, the Mediterranean Union as seen by the French leader was to run parallel to the European Union, without any institutional links. France, Turkey and possibly Egypt were to enjoy a privileged position, and play a key role in solving international conflicts in this area and developing cross-cultural dialogue. Sarkozy was also interested in the economic benefits and potential expansion of the sales market for French commodities in return for oil, gas and other resources.

While in Tangier (23 October, 2007), Sarkozy defined in his speech which countries would shape the new Mediterranean Union. The President openly said that it was a political project aimed at creating a French zone of influence in the Mediterranean. To a certain extent, it was also supposed to be a form of compensation for the privileged position Germany enjoyed in Central and Eastern Europe (Demesmay, 2008, p. 373-384). The plan for the new Union was to encompass only coastal Mediterranean countries. The President was confident that the countries of this region had sufficient capacities to face up to the political, economic and cultural challenges. Countries that were interested in the Mediterranean but were not located along the rim would be offered the role of observers.

He encouraged the European Commission to participate in the preparatory work under the principle of "cooperation and complementarity," the same way trade unions did, but in general, EU institutions were to be excluded from this process. President Sarkozy invited all Mediterranean leaders to an inauguration summit in France in July 2008 (Discours, 2007). 
It could be easily noticed that, initially, the French ideas lacked clarity and conciseness, and there were discrepancies between the Elysée Palace and Quai d'Orsay. There were discussions whether to extend the Mediterranean Union westwards, while other politicians and experts advocated the idea of including all coastal countries, including Croatia and Libya. Broader plans envisaged the extension of the existing Mediterranean Partnership (EUROMED) to include regional organisations such as the African Union. The participation of the European Commission as the representative of the European Union was deemed certain. The states that were interested in this form of cooperation but were not strictly located in the Mediterranean, such as Portugal or - more remotely - Germany, could apply for observer status (Schmid, 2007, p. 9).

The initial response of the most important partners - the addressees of this proposal - was not encouraging. Spain feared its own role in the Barcelona Process would be marginalised, therefore, Prime Minister José Luis Zapatero observed that they could only talk about the 'Barcelona Process plus'. Italy was waiting on developments and the United Kingdom declared it would not provide financial support to the new French project. Turkey was quick to realise that this offer was supposed to curb Turkish European ambitions and so showed no interest whatsoever (Schmid, 2008, p. 8).

The southern states addressed by the French plans showed some interest, but it was far from general approval. The most vehement criticism in the region was voiced by Libyan President Muammar Gaddafi, who approached Sarkozy's project as an element of imperial policy intended to destroy pan-Arabian unity. Many Arab countries found the prospect of Israeli partnership difficult to accept. To make things even more complicated, the interests of three countries from the francophone Maghreb (Morocco, Tunisia and Algeria) were in conflict due to Algerian-Moroccan competition in the Western Sahara (Albioni, 2008).

Sarkozy managed, albeit with difficulties, to persuade the leaders of the Romance countries, Romano Prodi and José Luis Zapatero, to approve the project only as late as December 20, 2007. Turkey was promised that its accession to the Mediterranean Union would not hinder accession negotiations with the European Union.

As a result of discussions and tensions between the Elysée Palace and Quai d'Orsay, three versions of the French plan emerged: (1) a comprehensive approach, where the members would encompass the countries already participating in the Barcelona Process within the European Union (from 1995), accounting for the membership of 39 countries (the EU-27 plus twelve states of the South: Algeria, Morocco, Tunisia, Egypt, Israel, the Palestinian Authority, Jordan, Lebanon, Syria, Turkey, Libya and Mauritania). The membership of Albania, Croatia, Bosnia and Herzegovina as well as Montenegro was also considered, which would mean 43 states altogether; (2) a restrictive approach, or the $6+6$ formula, with six northern (Spain, France, Italy, Malta, Portugal and Greece) and six southern states (Algeria, Libya, Morocco, Mauritania, Tunisia and Egypt); (3) the 'coastal countries' approach, accounting for 25 states with access to the Mediterranean Sea (Spain, Portugal, France, Monaco, Italy, Slovenia, Croatia, Bosnia and Herzegovina, Montenegro, Albania, Greece, Turkey, Malta and Cyprus, together with Morocco, Algeria, Tunisia, Libya, Egypt, Jordan, Israel, the Palestinian Authority, Lebanon, Syria and Mauritania). A majority of French politicians and diplomats were in favour of the most restrictive formula, to prevent accusations of doubling the Barcelona Process (Cholewa, 2008). 
From the beginning, Germany approached the French plans with the utmost caution, seeing more question marks than concrete proposals. They did not treat Sarkozy talking about the necessity to establish the Mediterranean Union seriously, considering his words as a worthless element of the election campaign. They believed that in this way Sarkozy was trying to win voters in southern France, where the National Front was particularly strong.

Berlin was carefully watching Sarkozy as the Minister of the Interior. His 2007 election programme was attractive, since it assumed deepened trans-Atlantic cooperation, reluctance towards Turkish integration with the European Union and a critical attitude towards the imperial ambitions of Russia. Chancellor Merkel, however, did not quite appreciate the French leader's hyperactivity and his not always well thought-out ideas (Radke, 2012, p. 37-40). Merkel treated the latest idea of the Mediterranean Union, which had not been agreed with Berlin, as yet another manifestation of French unilateralism which neglected the interests of other EU countries. She thought that, like in the early 1990s, when Paris was forcing the Euro-Mediterranean Partnership, France was trying to undermine European solidarity again. She did not like the fact that Sarkozy was pursuing the path of building a zone of interests that was beyond German control, thereby referring to the historical presence of colonial France in North Africa. Berlin did not conceal its scepticism or its view that this idea would double the Barcelona Process, which Germany had criticised before, anyway. Chancellor Merkel believed that the problems of illegal immigration, environmental protection, a free trade zone and the peace process in the Middle East concerned the entire European Union and should be resolved together. She argued that the French project raised the risk of the European Union being divided so that Germany would only be concerned with Eastern Europe, whereas France - with the South. She was also critical of the idea to limit the list of potential participants of the new initiative to those located in the Mediterranean. She knew that the idea of excluding EU institutions from this process and establishing new ones instead would be criticised in France as well. Attempts to appoint French socialist ex-Prime Minister, Michel Rocard, as the head of the Mediterranean Commission failed (Marten, 2008, p. 74-79; Jünemann, 2005, p. 7-13).

The increasing French criticism of the Barcelona Process, accusing it particularly of not having any long-term vision of developing contacts between the EU and Mediterranean countries, was received negatively in Germany. Germany felt offended, as the German presidency in the Council of the European Union placed significant emphasis on the implementation of the European Neighbourhood Policy. Berlin deflected French accusations of the lack of more significant successes in the Barcelona Process. The EU budget for 1995-2007 allocated 16 bln euro for this purpose, 70\% of which was actually utilised. Germany indicated that in the financial perspective for 2007-2013, that is for a much shorter period, the Barcelona Process allocated means of around 16 bln euro as well, which was evidence that the European Union approached the issue of the Mediterranean Partnership seriously (Merkel und Sarkozy, 2008; Berschens, Rinke, 2008).

German politicians realised that EU institutions supported their stance. The European Union watched the consistency of the whole initiative under the ENP and looked askance at the exclusive French project. Brussels resented Paris for criticising the Barcelona Process, as it meant indirect criticism of the Commission and other EU institu- 
tions. Guarding the consistency of the entire ENP, Brussels was aware of the risk of division and intensified internal conflicts between member states.

At the end of 2007, assisted by the media, the German government attempted to torpedo the French initiative, believing it was disadvantageous for the European Union. Chancellor Merkel and the Minister of Foreign Affairs, Frank-Walter Steinmeier, accused France of disintegrating the Union by its attempts to implement its own interests at the expense of the common budget. The German government even tried to persuade member states to limit their financial contributions to the development of the Mediterranean Union. This was also beneficial for the coalition partner, the SPD, as Minister Steinmeier decided to involve Germany in relations with Russia, inviting it to take part in a "Partnership for Modernisation" (Ratka, 2014, p. 112-113; Ayad, 2011, p. 18).

Chancellor Angela Merkel presented the position of Germany at the meeting of experts in Berlin on 5 December, 2007. She stated that if a Mediterranean Union encompassing coastal states had been built with EU money, others could say "let's build an Eastern European Union, for instance with Ukraine... In my opinion it is dangerous. The responsibility for the Mediterranean is as important for the north of the EU as the borders with Russia and Ukraine are for the south." In Merkel's opinion, a strong focus on these issues could blow the European Union up (Sarkozy, 2007).

It was clear that the initial negative response of Germany raised serious concerns in Paris. Sarkozy did not expect such an attitude. After all, he did try to embed his plan in the existing Mediterranean Partnership and the ENP. He was disappointed that important French ideas of how to activate the Mediterranean and its relations with the European Union were received coldly and sceptically instead of enjoying the expected approval (Schmid, 2008).

On 6 December, 2007, at a press conference organised during an informal meeting of the two leaders in Paris, Merkel left no doubts that the French project had to involve the entire Union ("die Mittelmeerregion ist unser aller Aufgabe in Europa") and both countries had to walk hand in hand to implement partnership programmes with East European and Mediterranean states. Sarkozy surrendered and said at the same conference that work would commence to involve all interested EU states in the Mediterranean Union project (Pressekonferenz, 2007).

The German counteraction in the European Council and European Parliament turned out to be successful. The German government's tough stance, supported among others by Polish Prime Minister Donald Tusk, forced Sarkozy to revise his plans. According to the agreement reached in Paris, the issue of the rapprochement of both governments was to be handled by the Director of one of the Departments at the Federal Chancellery and Advisor on Foreign and Security Policy to the Federal Chancellor, Christoph Heusgen, and a former ambassador of France in Washington and president Sarkozy's diplomatic advisor, Jean-David Levitte.

The breakthrough occurred in Hannover on 3 March, 2008, at an informal French-German summit held under the pretext of the opening of CeBIT computer fairs. The French President agreed to extend his plan to all 27 member states and emphasised that France and Germany "were unanimous both in fundamental issues and details." Merkel diplomatically responded that, in her view, the cooperation of the EU with the Mediterranean had "strategic significance" (EU: Merkel, 2008). Commentators observed the 
finesse with which Chancellor Merkel redirected the project as she desired. First, Chancellery experts ensured that the planning of the initiative was conducted in Brussels instead of Paris. Then the Chancellor involved Poland and Bulgaria, who demanded that the EU develop tighter ties with Ukraine and Black Sea countries. Poland was undoubtedly a beneficiary of this conflict, because it gained the approval and support from Berlin to develop the concept of the Eastern Partnership, initiated with Sweden (Kornelius, 2008; Stark, 2008, p. 235-240).

In line with French-German arrangements, at a meeting held on 13-14 March, 2008, the European Council approved the principle of the Mediterranean Union which was, as briefly stated, "to include the Member States of the EU and the non-EU Mediterranean coastal states." It invited the Commission to present to the Council the necessary proposals for defining the modalities of what would be called the "Barcelona Process: Union for the Mediterranean" (Oświadczenie, 2008).

After the Hannover meeting, France committed itself to the speedy implementation of the project which was to be specified by July 2008 and developed during the French presidency of the EU Council (July-December 2008). On 13 July, a day prior to the French national holiday, Sarkozy indeed managed to gather the leaders of 43 states, joined by the Arab League. Delegations of all EU states made their appearance there, while Muammar Gaddafi was absent. France succeeded in seating Syrian President Bashar al-Sadat and Israeli Prime Minister Ehud Olmert at the same table. The joint declaration published after the meeting featured the premise for the new organisation ("Barcelona Process: Union for the Mediterranean aims to build on that consensus to pursue cooperation political and socio-economic reform and modernisation on the basis of equality and mutual respect for each other's sovereignty") (Déclaration commune, 2008).

The tasks that had been defined earlier and were adopted at the summit involved the following: (1) de-pollution, waste disposal, protection of biological resources in the Mediterranean under the special strategy for the protection of the environment, which was to be implemented in 42 projects at a cost of 2 bln euro; (2) the construction of a highway from Casablanca to the Middle East, and of new connections between Mediterranean ports; (3) the creation of civil protection structures (management of natural disaster crises), education and training on crisis prevention; (4) an ambitious project to advance renewable energy on the basis of solar power plants; (5) the development of cooperation in the area of higher education (establishment of the first Euro-Mediterranean University in Portorož, Slovenia, to be followed by another one in Fez, Morocco; (6) support for small and medium business development financed from the Facility for Euro-Mediterranean Investment and Partnership instrument (FEMIP) (Déclaration, 2008; Hauser, 2014, p. 54-55).

The structures of the Union for the Mediterranean (UfM), planned in the July declaration, were designed by the end of 2008. There was a dispute over the location of the Union's Secretariat. Sarkozy suggested Tunis, whereas Germany opted for Brussels, for practical reasons. Finally, as proposed by Spain at the meeting of EU Ministers of Foreign Affairs, held in Marseille on November 4, 2008, the permanent secretariat (of one Secretary General supported by five Secretaries-Advisors) was located in Barcelona, where it would perform technical and executive functions. The management of 
the Union was to be exercised by the co-presidency composed of the representative of the EU state currently holding the presidency of the EU Council and the representative of one state from the South (beginning with France and Egypt). The team of Senior Officials was to constitute a permanent body obliged to hold regular meetings, prepare expert meetings, and draw up projects and reports. The Euro-Mediterranean Parliamentary Assembly (EMPA), operating since 2004, decided to rename itself the Parliamentary Assembly - Union for the Mediterranean in 2010. The Assembly is an advisory body operating under the Barcelona Process. Its participants include members of parliament from EU countries and the Mediterranean Partnership (Algeria, the Palestinian Authority, Egypt, Israel, Jordan, Lebanon, Morocco, Syria, Tunisia and Turkey), members of the European Parliament, as well as the members of parliaments of Mediterranean partner countries (Albania, Bosnia and Herzegovina, Croatia, Montenegro and Monaco) and of the Moorish parliament (Zgromadzenie Parlamentarne, 2014).

Another French-German clash concerned the issue of establishing the Mediterranean Bank, which was supposed to service Union projects in terms of finance. The Germans rejected French proposals and agreed only to a branch of the European Investment Bank to be set up. Ignoring German reservations, in May 2010, French state-owned financial institutions established a special capital association InfraMed with capital of $385 \mathrm{mln}$ euro (and a targeted 1 bln euro) to provide financial services to the development of cities, local infrastructure and power networks.

As mentioned above, the French presidency of the EU Council, held in the second half of 2008, was supposed to give momentum to the UfM project, but it did not. The Russian-Georgian war, which broke out in August, forced President Sarkozy to become actively involved in Eastern Europe. On 27 December, the Palestinian-Israeli conflict in Gaza broke out, leading to increased tension in the Middle East. All this coincided with the global financial crunch, which rapidly spread all over the euro zone and enforced intensive counter measures to be taken, primarily by France and Germany.

The French presidency of the EU Council raised the expectation as to the development of cooperation in the new form, therefore the fact that the new initiative was not operational in 2009 generated increased frustration. In this atmosphere Spain assumed the presidency of the EU Council, fully aware of the challenges to unblock the political standstill, launch the Union's Secretariat and implement new areas of cooperation. The prolonged discussions over where the organisation should be headquartered, the role to be given to Israel and the position of Secretary General undoubtedly had a negative impact on the whole initiative. First, the planning and outlining of the project was done in great haste, and then its implementation turned out to be chaotic. It took nineteen months to appoint a Jordanian, Ahmed Khalaf Masadeh as the Union's Secretary General, who then stepped down after several months (Parmentier, 2011).

Spain, as the initiator and promoter of the Barcelona Process, aspired to continue to strengthen regional integration in Southern Europe. Spain was facing a most difficult challenge to end the political stalemate between Israel and Arab states, which had paralysed the operations of the UfM. Spanish diplomacy was involved in the Middle East with poor results. It was more successful in the area of strengthening bilateral relations between the EU and Morocco, Tunisia, Israel and Jordan, which was included in its programme for the presidency (Nowak, 2010). 
After two years of the Union operating, there were no greater successes to speak of. The German government reported to the Bundestag in July 2010 that planning had started to implement the strategy for the protection of marine environment in the Mediterranean and for better supplies of potable water. The same concerned the issue of transport and the North African highway. There were 21 projects developed concerning civil protection and prevention of environmental disasters, the organisational framework for the solar project was outlined, and the set up and operation of SMEs was facilitated. The establishment of the Euro-Mediterranean University (EMUNI) in Portorež, Slovenia, was a tangible success. The University created a network of 142 members in 37 countries. Its tasks involved education and the exchange of students and scholars. Only one German higher education institution was involved in this project, namely the private International School of Management, with branches in Munich, Frankfurt am Mein, Hamburg, Cologne and Dortmund (Zwei Jahre, 2010; Ratka, 2010, p. 13-14).

The implementation of the UfM project was interrupted by the Arab revolutions that started in Tunisia in December 2010 to rapidly spread to Egypt and Libya. These surprised France, which maintained close relations with the dictators of Tunisia, Ben Ali, and Egypt, Hosni Mubarak, to the very end. It is worth reminding that merely three days prior to Ben Ali fleeing abroad, the French Minister of Foreign Affairs, Michèle Alliot-Marie, offered him help in dispersing the protesters and she did not conceal her mistrust towards the moderate opposition Islamic organisation Al-Nahda (the Renewal party) which was the engine behind the Tunisian transformations. This did not demonstrate France's being particularly well-informed of the Tunisian reality, as France was claiming. As in an attempt to counterbalance the bad impression and critical comments, President Sarkozy rapidly took the side of the Libyan opposition and opted for a military intervention. This must have flabbergasted Gaddafi, who was considered to be France's faithful friend and was believed to have covertly financed the 2007 election campaign of Sarkozy (Financement, 2014; Sarkozy, 2014). The French President also became quickly involved in a campaign against President Bashar al-Sadat, assembling a military coalition against him, albeit unsuccessfully (Schäfer, 2013, p. 7).

From the very beginning, Germany was on the side of the transformations in North Africa. Several months after Ben Ali was overthrown, on 12 February, 2011, German Minister of Foreign Affairs, Guido Westerwelle, arrived in Tunis, highly appreciating the pace of democratisation there, and declaring German aid at the initial amount of 3 mln euro for the fund for democracy. He also visited Algeria, Libya and Tunisia in February 2012. His most successful journey was marked by German promises to aid the new democratic government and further stabilisation of the situation in the country. Under the framework of the strategic Partnership for Transformation, Germany declared it was allocating around $30 \mathrm{mln}$ euro for the creation of work places, vocational training, scholarship programmes and improving the qualifications of state officials (Unruhen, 2011; Brössler, 2012). In March 2012, the head of Tunisian government, Hamadi Jebali, talked to Chancellor Merkel in Berlin, where regular German-Tunisian intergovernmental consultations were announced.

The most acute German-French dispute, however, concerned the events in Libya. Whereas France, the UK and US, both within the NATO and outside the alliance, provided active support in terms of arms and food to the insurgents fighting against 
Gaddafi, Germany remained highly restrained, limiting itself to offering moral support and the aid provided by a group of German military officers working in NATO logistics. To defend Germany, it can be said that from the beginning it declared sympathy for the Arab revolutionaries and condemned the Libyan dictator. German diplomacy supported the suspension of the UN embargo on the supplies of arms for the insurgents and was in favour of criminal proceedings to commence against the Libyan leader before the International Court of Justice in The Hague. Germany was also known to be sceptical as concerned military measures intended to protect civilians. Along with the US government, Berlin tried not to take a defined stance. The ultimate response was to depend on the Arab League's participation and actual commitment to this cause. These conditions were quickly fulfilled, and the US administration opted in the UN Security Council for a wide ban on flights over the area occupied by the insurgents. Although Berlin sympathised with the objectives of the resolution, on 17 March, 2011, the German representative in the UN Security Council abstained from voting on the adoption of the document in support of NATO operations in Libya (Kruk, 2011, p. 173).

Germany's stance generated exceptionally critical responses in France, the UK and the US, as well as among the German political elite. There were voices indignant at the fact that Germany did not vote alongside its old allies, but went with the new ones - Russia, China, India and Brazil (Herzinger, 2011; Varwick, 2011).

Under the pressure of mounting difficulties, towards the end of his office Sarkozy lost his zeal in pushing for the Union for the Mediterranean. There also emerged discrepancies between the Union's Secretariat and the European Commission in Brussels concerning the division of powers. EU countries became increasingly reluctant to finance this project. The retiring Secretary General, Ahmad Masa'deh, complained in his interviews that the Union's budget had been reduced by $60 \%$. The former European Commissioner for Enlargement, Günther Verheugen, also accused EU member states of a lack of interest in expanding cooperation with North Africa (Sebald, 2013).

The new plan, presented in Malta in October 2012 by new French President, François Hollande, was radically different from Sarkozy's original ideas, that tended to focus on concrete undertakings. The new idea was to make the Union a kind of executive entity of the European Neighbourhood Policy. The incumbent Secretary General of the Union for the Mediterranean, the Moroccan diplomat, Fathallah Sijilmassi, first and foremost was supposed to implement regional integration projects, such as the North African highway and the extension of the Erasmus Mundi programme. French Minister for Women's Rights, Najat Vallaud-Belkacem, was among the organisers of a conference to promote women's rights in the region in 2013 (Conference, 2013).

At the Malta meeting it was resolved to set up a common unit to combat drug smuggling, organised crime and illegal immigration. France put forward a joint industrial strategy aimed at the creation of new work places, facilitating business operations and cooperation in the area of transport of goods and people.

Repudiating his predecessor's ambitious project, Hollande intended to give a more modest form to the Union by means of providing a forum for dialogue among five North African states (Morocco, Tunisia, Algeria, Libya and Egypt) and five Mediterranean states (Spain, Italy, France, Portugal and Greece). The purpose of such narrowing of the scope of cooperation was to remove the issues related to the Israeli-Palestinian 
conflict from the everyday agenda, as it had frequently hampered Mediterranean cooperation in the past (Hollande, 2012).

It was quite easy to notice that France's interest was focused on three states: Morocco, Algeria and Tunisia. These were the targets of intensified activities of French diplomacy and business circles. At the same time, France became increasingly interested in the Sub-Saharan region. On account of the enormous problems generated by intense local conflicts, poverty and backwardness, the Sahel area called for a coordinated aid campaign, and France was not going to shun this responsibility.

Germany continued to treat the European Neighbourhood Policy, alongside the Barcelona Process and the Union for the Mediterranean, as important instruments to exert influence on the Mediterranean. Berlin became financially involved in the establishment of the Secretariat in Barcelona and took an active part in EU projects concerning solar power plants and wind farms. The Anna Lindh Euro-Mediterranean Foundation for the Dialogue between Cultures, established in 2005, became involved in this cooperation on the German side, fostering cultural exchange and cooperation between institutions that supported the emergence of a civil society. Headquartered in Alexandria, the Foundation operated through a network of national institutions in all European countries and Mediterranean partner countries, implementing its own projects participated in by organisations from North and South. Numerous joint academic initiatives with Mediterranean universities emerged, and in 2008 the Euro-Mediterranean University in Portorož was established. Political summits were accompanied by Civil Society Forums that attracted enormous interest from non-governmental organisations from the entire region, who could exchange experiences and plan joint projects (Praussello, 2011).

On German initiative, the European Union adopted the document on the "Partnership for Democracy and Shared Prosperity with the Southern Mediterranean" in March 2012. This new strategy was to be based on supporting democracy and the improved mobility of persons, but it also stressed combating illegal immigration, supporting the economic development that is conducive to social inclusion, facilitating the development of trade and investment, strengthening sectoral cooperation, particularly in the area of energy, and financial help ensured by the European Investment Bank and the European Bank for Reconstruction and Development (Partnerstwo, 2012).

Germany believed that the Union for the Mediterranean had not exhausted its potential. This could be seen in German efforts to replace the co-presidency of the Union, exercised by member states, by the EU, and in particular by the European External Action Service and the European Commission. Since the autumn of 2012, the UfM has been jointly managed by the European Union and Jordan. The German government continues to believe that the UfM can stabilise the situation in the entire region, influence its security, protection of human rights and counteract illegal immigration into the European Union (Schäfer, 2013, p. 9; Rossa, 2010, p. 149-166).

German commitment to the UfM project was exercised under the slogan of "peace, stability, prosperity." German politicians emphasised the importance of controlling and preventing illegal immigration from North Africa, combating Islamic terrorism, environmental protection, the creation of democratic institutions and human rights. As far as economics are concerned, the German government expressed particular interest in 
constructing solar power plants in North Africa, and wind farms. The issues of obtaining electricity from the African desert were handled by an informal group of experts forming the Trans-Mediterranean Renewable Energy Cooperation (TREC) network. The initially private initiative, named DESERTEC, was officially supported by the German government. The erection of solar power plants in the Sahara, and wind farms, was supposed to facilitate the supply of electricity to North African countries. Around $15 \%$ of the EU's demand was to be met from North African sources after 2050. This was the initiative of a physicist and a specialist in the area of energy, Gerhard Knies from the Club of Rome and Deutsches Zentrum für Luft und Raumfahrt. The DESERTEC foundation, followed by the DESERTEC Industrial Initiative and the DESERTEC University Network, with thirteen German shareholders, was subsequently established. In 2011, there were 21 associations from eight countries and 34 associated partners (Ruchser, 2013, p. 143).

Large German corporations, such as RWE, Siemens, Bosch and the MünchenerRück insurance company became involved in these projects. Apart from that, some German businesses were actively operating in North Africa on their own. RWE was planning to erect a solar power plant and wind farm in Morocco, and a solar power plant in Egypt. Germans held intensive talks with individual states. In January 2012, the "Energy Partnership" was agreed by Germany and Tunisia. This initiative was officially commenced in Berlin in January 2013. In July 2013, German Minister of Economy, Philipp Rősler, and his Moroccan counterpart, Fouad Douri, signed another bilateral agreement on energy partnership with Morocco (Un Partenriat, 2013).

The DESERTEC project invited extensive criticism, though. The criticism concerned the fact that changeable weather conditions would make the power supply ineffective. The power plants and installations would operate in a politically unstable region, where expensive equipment could become the target of terrorist attacks. The prices of renewable energy would be considerably higher, becoming completely unattractive for poor North African countries. All the Arab states had bureaucratic barriers and legal regulations that hindered business activity in this area. There were also fears that a rapid population increase in these countries could lead to increased local demand for electricity, and DESERTEC bosses feared that, instead of generating profit, their project would have to be treated as a certain form of aid to North Africa.

Similar to Germany, France also became involved in corresponding projects. Inspired by the French government, in 2010 the Medgrid consortium was established to specialise in the construction of a high-voltage network and transmission lines between Europe and North Africa. These initiatives enjoyed the support of the European Union. The cost of all these ventures was estimated at 400 bln euro, 50 bln of which was allocated to the construction of transmission lines. The Mediterranean Solar Plan (MSP) alone was planned to produce 20 gigawatts of power by 2020, including 3-4 gigawatts from photovoltaic cells, 5-6 - from wind farms and 10-12 - from solar power plants.

In 2011, the European Commission became actively involved in the implementation of these plans within the European Neighbourhood Policy, publishing the document "EU response to the Arab Spring: new package of support for North Africa and Middle East," which promised economic support for these states, for the Erasmus Mundus programme and assistance in building civil societies (Antwort, 2011). In 2012, the Eu- 
ropean Commission supported the project by Morocco, Germany, France, Italy and Spain to build a thermosolar installation in Morocco, for $600 \mathrm{mln}$ euro, to transmit electricity to Europe. The official agreement with Moroccan government was postponed, however, because EU countries lacked consensus on a common energy policy.

The global economic crisis and financial crunch in the euro zone considerably reduced French and German interest in the Mediterranean. Perhaps with the exception of Tunisia, the Arab revolutions did not inspire hopes that the situation would develop in the direction desired by these two countries and the entire EU. The Union for the Mediterranean had no achievements as a forum of international dialogue. Former French Minister of Foreign Affairs, Alain Juppé, addressed a parliamentary question asked in the national Assembly in June 2011, saying that the organisation would remain inactive as long as there was no progress in Israeli-Palestinian peace negotiations. The reactivation of the $5+5$ group was more a mark of the UE's impotence and escape from the problems of the Middle East. Germany continued to believe that the Union for the Mediterranean as an element of the European Neighbourhood Policy was promising. Berlin declared its support for North Africa on the assumption that in the past Germany did not have any negative experience in contacts with Arab nations. They had cooperated with regimes there, but not to the same extent as France. The German attitude to Israel and Palestine is cumbersome, however. The German economy has the enormous advantage of enjoying great respect in North Africa. Germany believes that, after the transformation of the former GDR and the countries of the former Soviet bloc, it has extensive experience in economic and social reforms which should be taken advantage of. Together with France, Germany can exert an advantageous impact on the transformation in North Africa, because they have similar outlooks on economic operations in this region, in particular in the area of energy, and they also care about curbing illegal immigration to the EU and combating terrorism (Jauréguy-Naudin/Cruciani, 2013, p. 143-160; Kłosowski, 2013).

\section{Bibliography}

Albioni R., (2008), The Union for the Mediterranean initiative. A view from Sothern Europe, "Documenti IAI", http://www.iai.it/pdf/DocIAI/iai0802.pdf.

Antwort der EU auf den arabischen Frühling: neues Unterstützungspaket für Nordafrika und den Nahen Osten (2011), European Commission - IP/11/1083 27/09/2011, http://europa.eu/ rapid/press-release_IP-11-1083_de.htm.

Baszkiewicz J. (1999), Historia Francji, Wrocław-Warszawa-Kraków.

Berschens R., Rinke A. (2008), Paris verprellt Berlin mit Mittelmeerunion, "Handelsblatt" of 6.02.2008.

Brössler D. (2012), Westerwelle im "Munsterland des Wandels", "Sủddeutsche Zeitung” of 9.01.2012.

Cholewa M. (2008), Francuska dyplomacja w okresie prezydencji w Radzie Unii Europejskiej (lipiec-grudzień 2008), "Biuletyn Międzynarodowy Instytutu Nauk Politycznych i Stosunków Międzynarodowych Uniwersytetu Jagiellońskiego", no 23, http://www.inp.uj.edu.pl/ c/document_library/get_file?uuid=f8033c3f-223d-478e-bda6-5cbabb83367e\&groupId= 3905854 . 
Conférence ministérielle de l'Union pour la Méditerranée sur le renforcement du rôle des femmes dans la société (2013), http://ufmsecretariat.org/fr/union-for-the-mediterranean-third-ministerial-conference-on-strengthening-the-role-of-women-in-society/.

Czapliński M. (1992), Niemiecka polityka kolonialna, Poznań.

Déclaration commune du sommet de Paris pour la Méditerranée Paris, 13 juillet 2008, http://www.diplomatie.gouv.fr/fr/IMG/pdf/Declaration_commune_UPM_bis.pdf.

Demesmay C. (2008), L'Allemagne face à l'Europe de Nicolas Sarkozy, "Politique étrangère", no 2.

Discours sur le thème de l'Union de la Méditerranée, Palais royal Marshan de Tanger (Maroc),-Mardi 23 octobre 2007, http://www.bvoltaire.fr/nicolassarkozy/discours-sur-le-theme-de-lunion-de-la-mediterranee, 7765 .

Die Zukunft Europas liegt im Süden (2007), "Frankfurter Allgemeine Zeitung” of 8.02.2007.

Deubner Ch. (1999), Frankreich in der Osterweiterung der EU 1989 bis 1997, "Politische Studien", no 363.

EU: Merkel bremst Sarkozy bei Mittelmeerunion aus (2008), "Der Spiegel” of 4.03.2008.

European Union, Trade in goods with MEDA (Excluding EU) - (Mediterranean Countries In The Euro-Mediterranean Partnership (2014), http://trade.ec.europa.eu/doclib/docs/2006/september/tradoc_117658.pdf).

Financement de la campagne de Sarkozy: la voix accusatrice de Kadhafi (2014), "La Libéracion" of 28.01.2014.

Gadi Ayad (2011), The Future of Euro-Mediterranean Regional Cooperation: The Role of the Union for the Mediterranean. European Institute of the Mediterranean, Barcelona.

Godin E., Vince N. (eds.) (2012), France and the Mediterranean. International Relations, Culture and Politics, Oxford-Bern-Berlin-Bruxelles-Frankfurt am Main-New York-Wien.

Hauser G. (2014), Die neue Nachbarschaftspolitik der Europäischen Union in der Mittelmeerregion - Herausforderungen für die EU, in: M. Staack, D. Krause, Europa als sicherheitspolitischer Akteur, Opladen-Berlin-Toronto.

Herzinger R. (2011), Libyen: Die deutsche Außenpolitik hat sich gründlich blamiert, "Die Welt" of 22.08.2011.

Hollande gegen Mittelmeerunion (2012), “Tagesblatt” of 18.07.2012.

Jauréguy-Naudin M., Cruciani M. (2013), Deutschland, Frankreich und die Energiepolitik, in: M. Koopmann, Neue Wege in ein neues Europa: die deutsch-französischen Beziehungen nach dem Ende des Kalten Krieges, Baden-Baden.

Jünemann A. (2005), Zehn Jahre Barcelona-Prozess. Eine gemischte Bilanz, "Aus Politik und Zeitgeschichte", Bd. 45/2005.

Kłosowski J. (2013), Unia na rzecz Regionu Morza Śródziemnego w martwym punkcie?, "Biuletyn Instytutu Zachodniego", no 131.

Kornelius S. (2008), Neues Etikett für eine alte Politik. Wie es Angela Merkel schaffte, Nicolas Sarkozy vom Plan einer eigenständigen Mittelmeerunion abzubringen, "Süddeutsche Zeitung" of 6.03.2008.

Koszel B. (2003), Rola Francji i Niemiec w procesie integracji Polski ze Wspólnotami Europejskimi/Uniq Europejska, Poznań.

Koszel B. (2008), Uprzywilejowane partnerstwo. Rzą Angeli Merkel (CDU/CSU-SPD) wobec integracji Turcji z Uniq Europejskq, "Rocznik Integracji Europejskiej", no 2.

Kumoch J. (2011), Idea Unii Śródziemnomorskiej - próba powstrzymania europejskich ambicji Turcji, in: Turcja i Europa. Wyzwania i szanse, ed. A. Szymański, Warszawa. 
Kruk A. (2011), Interests, Expectations and fears of Germany in the Face of the Arab Spring, in: The Arab Spring, ed. B. Przybylska-Maszner, Poznań.

Martnes S., Thorel J. (2013), Dissonanzen bei der Union für den Mittelmeerraum- Politische Konflikte und diplomatische Lösungen, in: Die Konsenswerkstatt. Deutsch französische Kommunikations- und Entscheidungsprozesse in der Euroapolitik, eds. C. Demesmay, M. Koopmann, Baden-Baden.

Marten S. (2008), Le couple franco-allemand: nécessaire mais pas suffisant, "Questions internationales", mai-juin.

Nowak A. (2010), Prezydencja hiszpańska 2010. Śródziemnomorskie priorytety a polityka wschodnia Unii Europejskiej, “Analizy Natolińskie”, no 5.

Merkel und Sarkozy einigen sich über Mittelmeerunion (2008), "Frankfurter Allgemeine Zeitung" of 4.03.2008.

Oświadczenie w sprawie "Procesu Barcelońskiego: Unii Śródziemnomorskiej” (2008), Rada Europejska w Brukseli 13-14 marca 2008 r. Konkluzje prezydencji, http://www.consilium.europa.eu/uedocs/cms_data/docs/pressdata/PL/ec/99414.pdf.

Parmentier F. (2011), Powrót Poludniowego Sasiedztwa, file://C:/Users/Gabinet/Desktop/ new_3_4_2011_164_powrot_poludniowego_sasiedztwa\%20(1).pdf.

Partnerstwo na rzecz demokracji i wspólnego dobrobytu z poludniowym regionem Morza Śródziemnego (2012), http://europa.eu/legislation_summaries/external_relations/relations_with_ third_countries/mediterranean_partner_countries/rx0024_pl.htm.

Praussello F. (ed.) (2011), Euro-Mediterranean Partnership in the Aftermath of the Arabian Springs, Milano.

Pressekonferenz von Bundeskanzlerin Angela Merkel und dem französischen Staatspräsidenten Nicolas Sarkozy (Paris, 6. Dezember 2007), http://www.deutschland-frankreich.diplo.de/ Blaesheim-Treffen-in-Paris-6,2918.html.

Radke K. (2012), Mehr gezappelt als bewegt. Die bilateralen Beziehungen aus deutscher Perspektive, "Dokumente. Zeitschrift für den deutsch-franzősischen Dialog", no 1.

Ratka E. (2010), Un premier bilan mitigé. L'Allemagne et l'Union pour la Méditerranée, "Dokumente. Zeitschrift für den deutsch-franzősischen Dialog", no 4.

Ratka E. (2014), Deutschlands Mittelmeerpolitik. Selektive Europäisierung von Mittelmeerunion bis zum Arabischen Frühling, Baden-Baden.

Rezolucja Euro-Śródziemnomorskiego Zgromadzenia Parlamentarnego w sprawie oceny procesu barcelońskiego w przededniu dziesiatej rocznicy jego istnienia przyjęta w dniu 15 marca $2005 \mathrm{r}$. w Kairze (Egipt), http://oide.sejm.gov.pl/oide/images/files/empa/1_kair_pl.pdf.

Sarkozy et financement Kadhafi: Me Ceccaldi répond à Yves Thréard (2014), "Le Figaro" of 10.03.2014.

Sarkozys Mittelmeer-Union Merkel sieht Sprengstoff für EU (2008), http://www.n-tv.de/politik/Merkel-sieht-Sprengstoff-fuer-EU-article281169.html.

Rossa D. (2010), Partnerstwo śródziemnomorskie i Unia dla Morza Śródziemnego jako filary bezpieczeństwa w regionie, "Zeszyty Naukowe Akademii Marynarki Wojennej”, no 2.

Ruchser M. (2013), Erst Jasmin, dann Fukushima: Wie geht es weiter mit "Strom aus der Wüste”, in: Europa und der Arabische Frühling, eds. P. Bender, G. Walter, Baden-Baden.

Schäfer (2013), Nordafrika-Politik zwischen Idealen und Interessen Deutschland und Frankreich müssen ihre Unterstützung besser aufeinander abstimmen, "DGAPanalyse", no 1.

Schmid D. (2007), Méditerranée: le retour des Français?, "Confluences Méditerranée”, No. 63.

Schmid D. (2008), Die Mittelmeerunion - ein neuer französischer Motor für die europäische Mittelmeer-Politik?, "DGAPanlayse", no 1. 
Schumacher T. (2009), Deutschland, die Union für das Mittelmeer und die südliche Nachbarschaft: Interessen und Perspektiven, "Mediterranes", no 1, http://ema-hamburg.org/media/DE/medi/ Ausgaben/1-2009/12_pdfsam_Mediterranes_Heft_1.pdf.

Sebald Ch. (2013), Mittelmeerunion: Wunschgebilde oder tragfähige Perspektive?, http://www.treffpunkteuropa.de/Mittelmeerunion-Wunschgebilde-oder-tragfahige-Perspektive,05638.

Stark H. (2008), Die französische EU-Ratspräsidentschaft 2008 - zwischen aktuellem Krisenmenagement und strategischen Weichenstellung, "Integration" no 3.

Unruchen in Nordafrika (2011), "Der Spiegel” of 12.02.2011.

Un Partenariat énergétique entre l'Allemagne et le Maroc (2013), Ambassade d' Allemagne a Rabat, $\mathrm{http} / / /$ www.rabat.diplo.de/Vertretung/rabat/fr/seite_deutsch-marokk_energiepartnerschaft.html.

Varwick J. (2011), Unzuverlässiger Bündnispartner. Ist Deutschland aussenpolitisch isoliert?, "Internationale Politik-on line" of 23.08.2011, http://www.internationalepolitik.de/2011/08/23/ unzuverlassiger-bundnispartner-2/.

Wójcik A. (2008), Jakie doświadczenia ze wspótpracy w regionie Morza Śródziemnego moga być przydatne w konstruowaniu Strategii UE dla regionu Morza Baltyckiego?, "Biuletyn Analiz UKIE", no 19, https://polskawue.gov.pl/files/polska_w_ue/Polska_a_polityki_UE/Strategia_Morza_Baltyckiego/A.Wojcik.pdf.

Zgromadzenie Parlamentarne Unii dla Śródziemnomorza (ZPUŚ) / Eurośródziemnomorskie Zgromadzenie Parlamentarne (EMPA) (2014), http://oide.sejm.gov.pl/oide/index.php?option=com_content\&view=article\&id=14653:eurorodziemnomorskie-zgromadzenie-parlamentarne-empa\&catid $=39 \&$ Itemid $=703$.

Zwei Jahre Union für das Mittelmeer. Antwort der Bundesregierung auf die kleine Anfrage der Fraktion der SPD (2010), Deutscher Bundestag. Drucksache no 17/2523, http://dip21.bundestag.de/dip21/btd/17/026/1702669.pdf.

\section{Summary}

The Union for the Mediterranean, established in 2008 by France, was intended to strengthen French influence in the region. After Germany intervened, this exclusively French project was expanded to encompass the entire European Union, which provided financial support from the European Neighbourhood Policy. The immense political, economic and social problems facing the south of the Mediterranean prevented the Union for the Mediterranean from operating efficiently there. Under the circumstances of the crisis in the euro zone, and after the Arab revolutions, France and Germany intend to continue to support the democratisation process in the region and they have come up with numerous initiatives, especially in the field of energy, cross-cultural dialogue and educational projects. They also support measures to combat terrorism and curb illegal immigration into the European Union.

Key words: France, Germany, Union for the Mediterranean, European Union

\section{Unia dla Śródziemnomorza w polityce Francji i Niemiec}

\section{Streszczenie}

Utworzenie przez Francję w 2008 r. Unii dla Śródziemnomorza miało ugruntować jej wpływy na obszarze Morza Śródziemnego. Wskutek interwencji Niemiec ekskluzywny projekt francuski rozciagnięty został na całą Unię Europejską, która wsparła ją środkami finansowymi 
z programu Europejskiej Polityki Sąsiedztwa. Olbrzymie problemy polityczne, gospodarcze i społeczne występujące w obszarze południowej części Morza Śródziemnego uniemożliwiły Unii dla Środziemnomnorza skuteczne działania. W warunkach kryzysu strefy euro i po rewolucjach arabskich Francja i Niemcy zamierzają nadal wspierać proces demokratyzacji tego regionu i występują z licznymi inicjatywami, zwłaszcza w dziedzinie energetyki, dialogu międzykulturowego i programów edukacyjnych. Wspierają działania na rzecz walki z terroryzmem i ograniczenia nielegalnej emigracji do Unii Europejskiej.

Słowa kluczowe: Francja, Niemcy, Unia dla Śródziemnomorza, Unia Europejska 